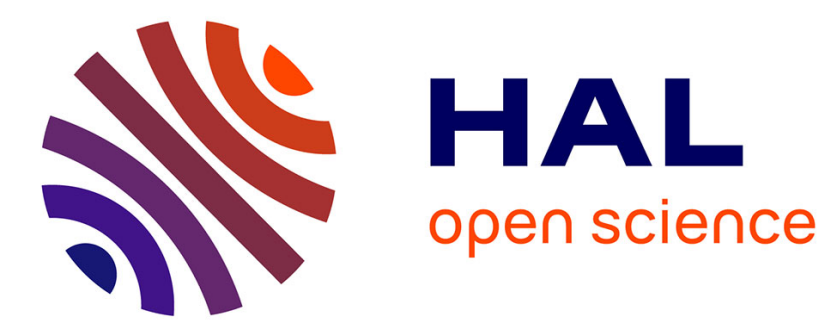

\title{
On diet and gut size in non-human primates and humans: is there a relationship to brain size?
}

\author{
Claude Marcel Hladik, David J. Chivers, Patrick Pasquet
}

\section{To cite this version:}

Claude Marcel Hladik, David J. Chivers, Patrick Pasquet. On diet and gut size in non-human primates and humans: is there a relationship to brain size?. Current Anthropology, 1999, pp.695-697. hal00548918

\section{HAL Id: hal-00548918 \\ https://hal.science/hal-00548918}

Submitted on 20 Dec 2010

HAL is a multi-disciplinary open access archive for the deposit and dissemination of scientific research documents, whether they are published or not. The documents may come from teaching and research institutions in France or abroad, or from public or private research centers.
L'archive ouverte pluridisciplinaire HAL, est destinée au dépôt et à la diffusion de documents scientifiques de niveau recherche, publiés ou non, émanant des établissements d'enseignement et de recherche français ou étrangers, des laboratoires publics ou privés. 
HLADIK, C.M. CHIVERS, D.J. \& PASQUET, P. (1999) - On diet and gut size in non-human primates and humans: is there a relationship to brain size?

Current Anthropology, 40 : 695-697.

\title{
On diet and gut size in non-human primates and humans: is there a relationship to brain size?
}

\author{
by C.M. Hladik*, D.J. Chivers ${ }^{* *}$ and P. Pasquet ${ }^{* * *}$ \\ *Éco-Anthropologie, Muséum National d'Histoire Naturelle, Brunoy, France. \\ ** Veterinary Anatomy, Cambridge University, UK. \\ *** Dynamique de l'évolution humaine, CNRS, Paris, France.
}

In 1995, Aiello and Wheeler (CA 36: 199-221) proposed the "expensive-tissue hypothesis" related to the evolutionary forces implied in the hominid brain size increase. They focused on the shift to a high-quality diet and the corresponding gut adaptation: a reduced intestinal mass, by lowering considerably the relative energetic cost, may permit disposal of sufficient energy to cover the extra-expenditure of a larger brain. This exciting hypothesis provides a new element in the debate on the relationship between diet, energetics and encephalization, but the main argument suffers from flaws that we propose to highlight and comment here.

To support their hypothesis, the authors refer to a set of measurements of the intestinal tract of primates published by two of us (Chivers and Hladik, 1980), with some adjustments, compared to human intestinal tract (data from Aschoff et al., 1971). However, in a recent review of morphological and sensory adaptations to diet in primates, Hladik and Pasquet (in press) highlighted the partial circularity of the arguments developed by Aiello and Wheeler: the sample they used to defined non-human primate gut size (or gut weight) is likely to include several species of higher primates with specialized, or partly, folivorous diets rich in fiber. Accordingly, the expected gut size for a "standard human" - derived from this sample and larger than observed - could reflect, to some extent, differences in diet between the reference primate sample and humans.

Indeed, the pioneering paper including measurements of gut size was a study of the allometric relationship of gut and body size for various dietary adaptations. It was disappointing that Aiello and Wheeler did not use the measurements on human guts, made with a similar method, introduced in papers published in the 80's (e.g. Mac Larnon et al., 1986). Some of these data are reported here (fig. 1), combined with one of the original figures (Chivers and Hladik, 1980) illustrating the reduced major axis for three major dietary tendencies of primates and other mammals (folivore / frugivore / faunivore). The human specimens fall, as expected, on the main axis for frugivore, a gross category corresponding to fruit and seed eaters (or omnivorous, when occasional meat eating is practiced). 
Gut areas rather than weights have been used in this study. Data on areas are more accurate than weights since most weighing was performed after the removal of excess moisture of gut parts dissected in water; hence published weights must be used with caution. Furthermore, area measurement of relaxed gut parts was aimed at comparing functional capacity (i.e. absorption and the size of fermenting chambers) in relation to body functional size (Hladik, 1977). Again, the functional size ( $\mathrm{L}^{3}$, using sitting height, $\mathrm{L}$, as an analog for humans to be compared to body+head in other mammals) was chosen rather than the actual weight to avoid the bias due to fat accumulation when comparing animals of various size and weight (especially zoo specimens vs. wild specimens) to infer functional evolutionary perspectives.

The slopes of the regression lines for the three major dietary tendencies (fig. 1) differ significantly $(\mathrm{p}<0.05)$. Accordingly, the comparison of gut absorptive areas of animals differring in body size would seem to account for different allometric relationships. The absorptive areas vary according to body size, scaled to $\mathrm{L}^{2.64}, \mathrm{~L}^{2.37}$ and $\mathrm{L}^{1.98}$, respectively for folivores, frugivores and faunivores. A geometrical model was proposed, to explain the functional effect of allometry so that animals with high-quality diet (faunivores, and to a lesser extend, frugivores) show a reduced absorptive area, as compared to folivores, assessing, for all species, a contant flux per unit mucosal area (Chivers and Hladik, 1980).

A recent study by Pappenheimer (1998), on the significance of absorptive mechanisms in relation to scaling of dimensions of small intestines, goes one step further towards the interpretation of the above allometric relationships. In large species, transcellular absorption is low as compared to small species, whereas paracellular fluid absorption is greater in large species than in small species. Paracellular fluid absorption may dominate in large faunivores with a small mucosal area (scaled to $\mathrm{L}^{2}$ in fig. 1), whereas in large folivorous species, the relatively diluted intestinal fluid and the low rate of transcellular absorption could be compensated by the increase of the mucosal area (tending towards $\mathrm{L}^{3}$ rather than $\mathrm{L}^{2}$ ), the frugivores being intermediate.

If we consider the nutritional requirements, although little is known about the relationship between total energy expenditure and hominization, we agree with Leonard and Robertson (1992), who noted that, in anthropoids, the energy expenditure is positively correlated to day range and high-quality diet. Changes in energy requirements could have been particularly important with the emergence of early Homo, and probably accentuated in Homo erectus, with the progressive occurrence of hunting or scavenging in complement of foraging for fruit, tubers and seeds. Is this adaptation linked to a necessary change in gut size?

The "faunivore" trend, as well as the "folivore" trend, are morphological specialization - corresponding to different allometric relationships - that are not likely to allow a large plasticity, as for any specialized character. A specialized carnivorous adaptation in humans that would correspond to a minimized gut size is obviously not supported by our data (fig. 1). Large variations presently observed in human diets (Hladik and Simmen, 1996) are probably allowed by our gut morphology as an unspecialized type of "frugivore", a flexibility allowing Pygmies, Inuit, and several other populations, present and past, to feed extensively on animal matter, for whom most of the energy is mostly derived from fat (Speth, 1987). 
The main point of Aiello and Wheeler was based on the relationship between body mass and Basal Metabolic Rate (BMR): the Kleiber line characterizing relationship betwen BMR and body size is identical for all mammals, including humans. Since maintenance of gut tissue is as expensive as that of the brain tissue, Aiello and Wheeler proposed that gut reduction compensated brain increase. Given the data in hand, the reduction might concern the whole body parts (with a ratio to brain size smaller than in other mammals), rather that a reduction exclusively focused on gut tissue.

In conclusion, Homo sapiens does not appear as an exception among other primates, in terms of dietary trend and gut size. There is no doubt that our species need a rich diet to cover large energy expenses; but relatively no more than many Cebidae and Cercopithecidae feeding on sweet fruits complemented by the protein and fat of a large proportion of insects. The areas of mucosa that have been actually measured in humans do not show any trend towards a reduced intestine that would have allowed a supplement of energy for a large brain.

\section{Reference cited}

Aiello, L.C. And P. Wheeler. 1995. The Expensive-Tissue Hypothesis. The brain and the digestive system in human and primate evolution. Current Anthropology, 36: 199-221.

Aschoff, J., B. GÜNTHER AND K. KRAMER. 1971. Energiehaushalt und Temperaturregulation. Munich: Urban and Schwartzenberg.

Chivers, D.J. And C.M. Hladik. 1980. Morphology of the gastrointestinal tract in primates: comparisons with other mammals in relation to diet. Journal of Morphology, 166: 337-386.

HLADIK, C.M. 1977. Le régime alimentaire des Primates et son adaptation aux ressources du milieu forestier. Thesis (Doctorat d'Etat), 2 volumes, Muséum National d[Histoire Naturelle \& Université Paris 6.

Hladik, C.M. And P. Pasquet. (in press). Evolutionary aspects of feeding behavior: morphological and sensory adaptations (in French). Bulletins et Mémoires de la Société d'Anthropologie de Paris.

Hladik, C.M. And B. Simmen. 1996. Taste perception and feeding behavior in nonhuman primates and human populations. Evolutionary Anthropology, 5: 58-71.

LEONARD, W.R. AND RoBERTSON, M.L. 1992. Nutritional requirements and human evolution: a bioenergetics model. American Journal of Human Biology. 4: 179-195.

Mac Larnon, A.M., R.D. Martin, D.J. Chivers, and C.M. Hladik. 1986. “Some aspects of gastro-intestinal allometry in primates and other mammals", in Définition et origines de l'Homme. Edited by M. Sakka, pp. 293-302. Paris: Editions du CNRS.

PAPPENHEIMER, J.R. 1998. Scaling of dimensions of small intestines in non-ruminant eutherian mammals and its significance for absorptive mechanisms. Comparative Biochemistry and Physiology, Part A 121: 45-58.

SPETH, J. 1987. Early hominid subsistence strategies in seasonal habitats. J. Archaeol. Sci., 14: 13-29. 
Figure 1. Allometric relationship between the area of the absorptive mucosa of the digestive tract and functional body size in three distinct group of species, according to major dietary patterns (in a total of 117 primates of 50 species, among 180 mammals; after Chivers and Hladik, 1980). Similar measurements of 4 post-mortem human specimens (samples P81 of Hladik and Chivers) are reported on the figure. Functional body size $\left(10^{-3} \mathrm{~L}^{3}\right)$ is plotted along a logarithmic scale $(\mathrm{L}=$ nose to anus for animals; sitting height for humans).

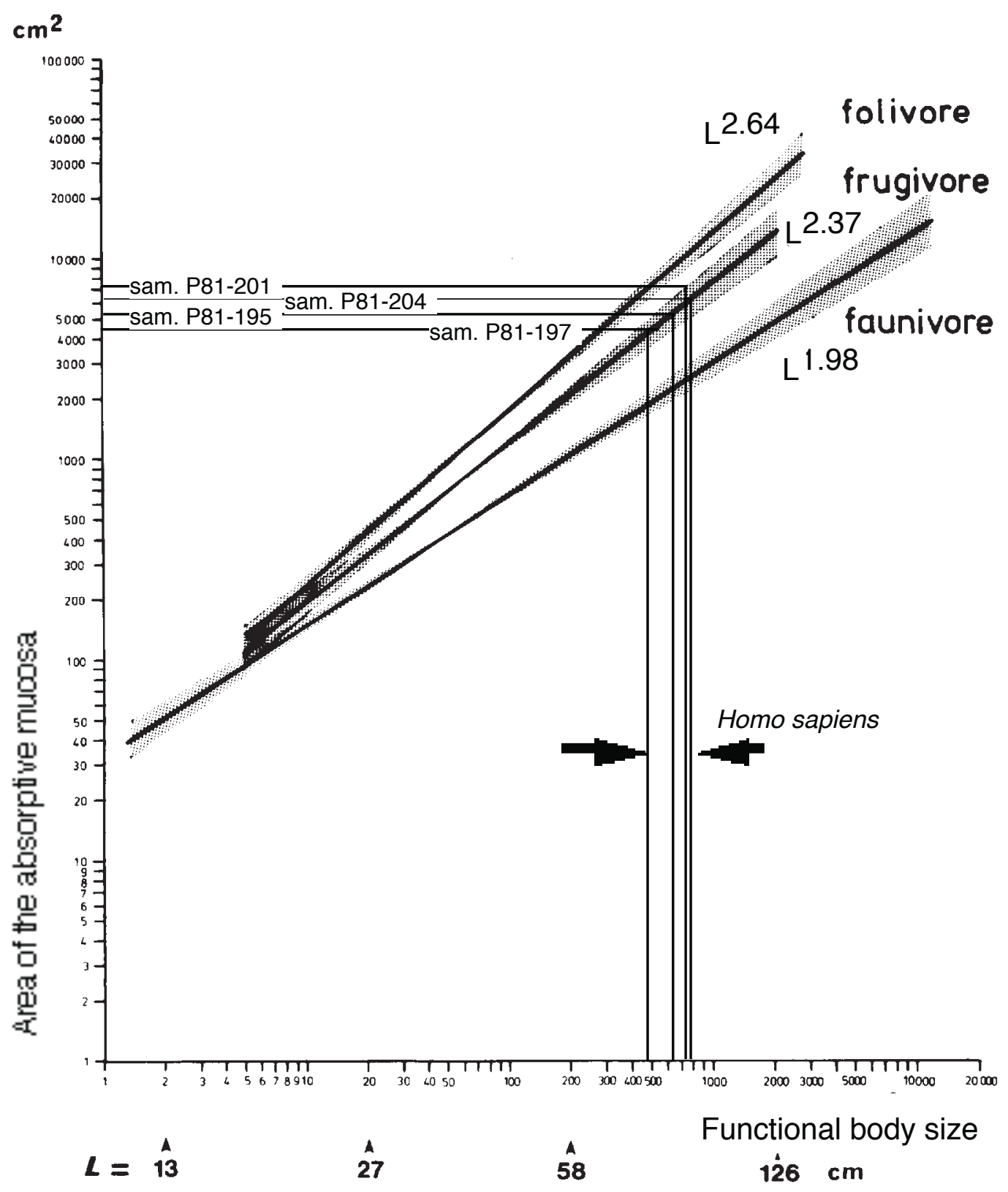

